\title{
Berpikir Semantik (semantic thinking) Siswa dalam Pemecahan Masalah Matematis
}

\author{
${ }^{1}$ Marwan La Gampa, ${ }^{2}$ Hery Suharna, ${ }^{3}$ Nurma Angkotasan \\ ${ }^{1,2,3}$ Program Studi Pendidikan Matematika, Universitas Khairun
}

\begin{abstract}
ABSTRAK
Penelitian ini bertujuan untuk melihat berpikir semantik (semantic thinking)siswa dalam pemecahan masalah matematis. penelitian ini merupakan jenis penelitian eksploratif dengan pendekatan deskripsi kualitatif, subjek penelitian ini adalah peserta didik kelas VII SMP N 14 HALMAHERA SELATAN, dalam pemilihan subjek peneliti melakukan tes kemampuan matematika, hasil tes tersebut dikategorikan menjadi kategori tinggi, sedang, dan rendah. Pengumpulan data penelitian ini adalah tugas pemecahan masalah (tpm), wawaancara, dan rekaman think out load. Analisis dalam penelitian ini adalah mentranskip data verbal yang dikumpulkan, kategorisasi data, mereduki data, memeriksa keabsahan data/ triangulasi data, menelaah data, dan penarikan kesimpulan. Berdasarkan Hasil penelitian dari masing-masing kategori pertama kemampuan matematika tinggi: Berpikir semantik siswa dalam menyelesaikan pemecahan masalah matematis dimulai dari informasi/pengetahuan yang digunakan untuk merespon berasal dari dalam diri terhadap fenomena - fenomena yang memerlukan jawaban fakta dan mencari jawaban sendiri dari persoalan yang diangkat, menyadari kesalahan dan memperbaikinya, dan mengkomunikasikan ide dengan simbol atau gambar.Kedua kemampuan matematika sedang: Berpikir semantik siswa dalam menyelesaikan pemecahan masalah matematis dimulai dariinformasi/pengetahuan yang digunakan untuk merespon berasal dari dalam diri (internal), menjelaskan yang telah dilakukan terkait lambang atau simbol, dan mengkomunikasikan ide dengan simbol atau gambar yang selaras.Ketiga kemampuan matematika rendah: Berpikir semantik siswa dalam menyelesaikan pemecahan masalah matematis dimulai dariinformasi/pengetahuan yang digunakan untuk merespon berasal dari dalam diri, kemudian menyusun lambang atau simbol dan merepsentasikan data.
\end{abstract}

Kata kunci : Berpikir Semantik dan Pemecahan Masalah matematis 


\section{PENDAHULUAN}

Menurut UU No. 23 tahun 2003 tentang Sistem Pendidikan Nasional Bab IV Pasal 3, sebagaimana dikutip oleh Achmad Munib et al (2012: 20), Pendidikan Nasional berfungsi untuk mengembangkan kemampuan dan membentuk watak serta peradaban bangsa yang bermartabat dan dalam rangka mencerdaskan kehidupan bangsa, bertujuan untuk berkembangnya peserta didik agar menjadi manusia yang beriman, bertaqwa kepada Tuhan Yang Maha Esa, berakhlak mulia, sehat, berilmu, cakap, kreatif, mandiri, dan menjadi warga negara yang demokrasi serta bertanggung jawab. Keberadaan pendidikan yang sangat penting tersebut, terintegrasi dalam pembelajaran di sekolah. Salah satu mata belajaran wajib yang harus dipelajari peserta didik adalah matematika.

Matematika diartikan oleh Johnson dan Rising (Suherman, 2014: 19) sebagai pola berpikir, pola mengorganisasi, pembuktian yang logik, bahasa yang menggunakan istilah yang didefinisikan dengan cermat, jelas, dan akurat representasinya dengan simbol dan padat. proses berpikir adalah proses yang dimulai dari penemuan informasi (dari luar atau diri peserta didik), pengolahan, penyimpanan dan memanggil kembali informasi itu dari ingatan peserta didik melalui berpikir.

Semantik dalam bidang matematika pada umumnya terkait dengan lambang, simbol, tanda, dan lain sebagainya. Seperti halnya semantik menurut Tarigan adalah menelaah lambang atau tanda (simbol) yang menyatakan makna, hubungan makna satu dengan yang lain, dan pengaruhnya terhadap manusia dan masyarakat serta pada dunia pendidikan salah satunya dibidang matematika. Sehingga dengan hal itu, berpikir semantik sangat di butuhkan dalam menyelesaikan soal -soal matematika yang melibatkan lambang atau tanda (simbol).

Berpikir semantik adalah informasi atau data berasal dari dalam diri peserta didik yaitu mengolah informasi berdasarkan pengetahuan yang telah di miliki terkait lambang atau simbol dan tidak di pengaruhi oleh lingkungan atau eksternal. Proses berpikir semantik selanjutnya peserta didik bisa menjelaskan apa yang dilakukan yaitu peserta didik mampu menggunakan informasi yang sudah dimilikinya dalam menjelaskan apa yang dilakukan. Peserta didik menyadari kesalahan (jika ada kesalahan) dan memperbaiki kesalahannya tersebut yaitu pada saat peserta didik menyadari kesalahan yang telah dilakukan dan peserta didik tersebut tidak mau melakukan kesalahan yang sama di masa yang akan datang. Selanjutnya adalah peserta didik mampu mengkomunikasikan ide dengan simbol atau gambar.

Polya (Wardhani, 2016: 26-34) menjelaskan bahwa pemecahan masalah adalah menemukan makna yang dicari sampai akhirnya dapat dipahami dengan jelas. Memecahkan masalah berarti menemukan suatu cara menyelesaikan 
masalah, mencari jalan ke luar dari kesulitan, menemukan cara di sekitar rintangan, mencapai tujuan yang diinginkan, dengan alat yang sesuai.

SMP Negeri 14 Halmahera Selatan beralamat di Jl. Raya Gandasuli, Kec. Bacan Selatan, Kab. Halmahera Selatan. Dipilihnya sekolah ini karena berdasarkan informasi yang peneliti dapatkan dari salah satu guru matematika (Citra Tifa La Apu, S.Pd) bahwa tingkat belajar peserta didik terhadap suatu pelajaran kurang, hal ini dikarenakan pengaruh pergaulan peserta didik yang kurang baik yang didapatkan dari lingkungan sekitar, serta SMP Negeri 14 Halmahera Selatan merupakan sekolah asal peneliti. Peneliti mengambil materi pertidaksamaan linear satu variabel karena merupakan salah satu materi matematika yang ada pada kelas VII, bab 2 semester genap. Bentuk pertidaksamaan linear satu variabel di dalamnya menggunakan simbol atau huruf tertentu yang mempunyai makna. Karena pertidaksamaan linear satu variabel terkait dengan simbol/tanda maka peneliti mengkaitkan dengan semantik karena semantik berbicara tentang simbol - simbol/ tanda -tanda yang mempunyai makna.
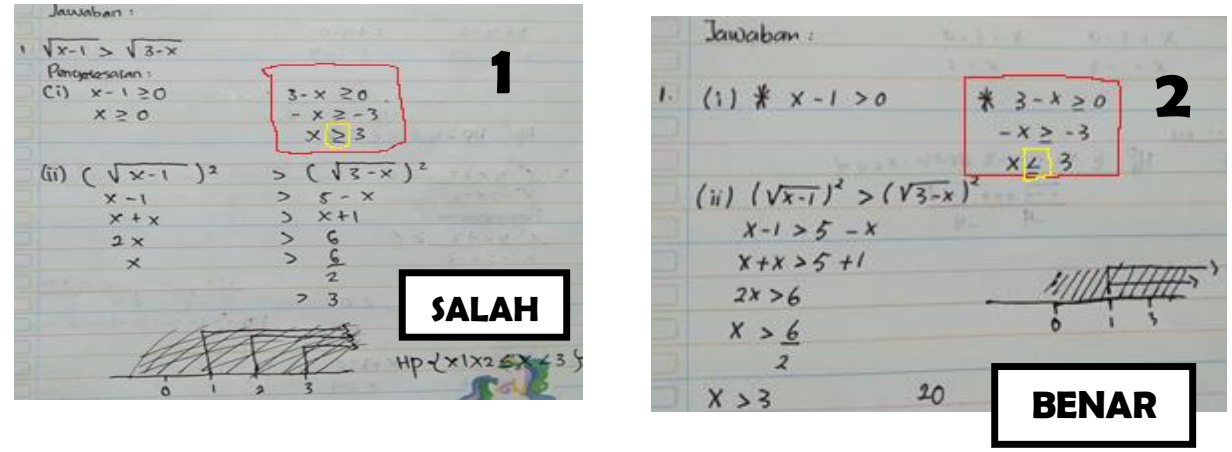

Peneliti menganalisis hasil tes pekerjaan siswa tentang pertidaksamaan irasional. Hasil analisis tersebut membuktikan bahwa sebagian peserta didik masih belum mampu dan sebagian sudah mampu menggunakan daya berpikir semantik, dalam memaknai simbol/tanda yang didalamnya mempunyai arti dalam pertidaksamaan serta simbol/tanda dalam materi matematika lainnya. Melihat hal itu, peneliti ingin memperbaiki kesalahan siswa dalam memaknai simbol/tanda dengan mengolah berpikir siswa terkait dengan masalah tersebut.

\section{METODE PENELITIAN}

\section{Jenis Penelitian}

Penelitian ini bertujuan untuk mendeskripsikan tentang berpikir semantik (Semantic Thinking) siswa dalam pemecahan masalah matematis. Jenis penelitiannya adalah eksploratif dengan pendekatan deskripsi kualitatif. Subjek 
penelitian siswa kelas VII SMP N 14 Hal-Sel. Dalam pemilihan subjek peneliti melakukan tes kemampuan matematika. Hasil tes tersebut dikatagorikan menjadi kategori rendah, sedang, dan tinggi. Selanjutnya dari masing-masing kategori tersebut diambil minimal 1 orang untuk dijadikan subjek penelitian.

\section{Instrumen Penelitian}

Instrumen tes yaitu tes TPM $1 \& 2$ tertulis yang berisi soal pemecahan masalah yang terdiri dari 1 soal masing-masing TPM. Penyusunan soal tes dimulai dengan penyusunan pemecaham masalah (TPM) diperoleh draf I, selanjutnya validasi ahli, draf TPM yang valid, selanjuntnya uji keterbacaan dan sampai pada draf layak. Berikut ini disajikan bagan penyusunan intrumen penelitian. Wawancara bertujuan untuk mengetahui berpikir semantik (semantic thinking) siswadalam pemecahan masalah matematis.

\section{Teknik Analisis Data}

Hasil dari pengumpulan data yaitu hasil pengamatan peneliti sebagai instrumen, tugas pemecahan masalah (TPM) dan wawancara. Teknik analisis data dapat terlihat pada bagan berikut:

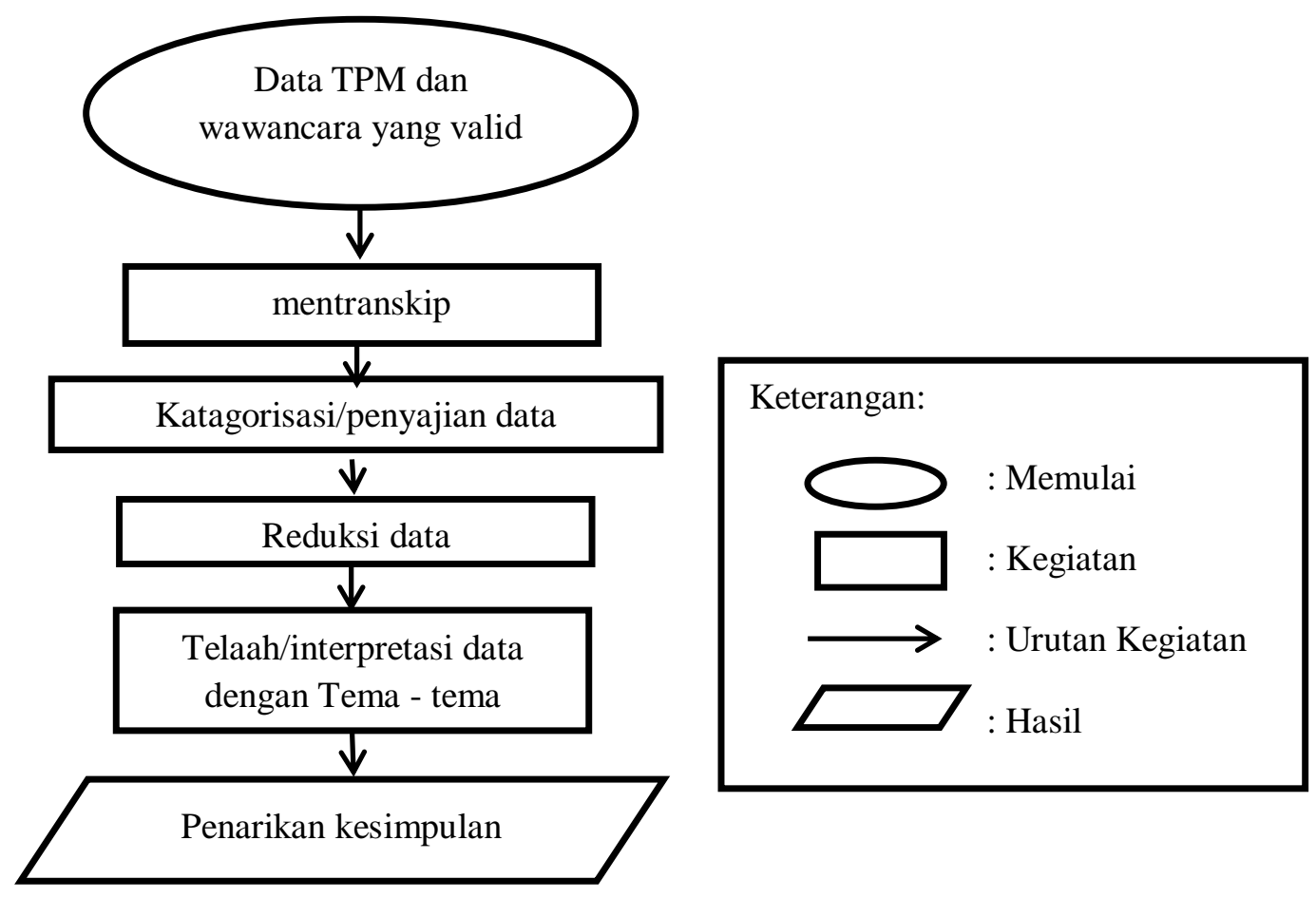

\section{HASIL PENELITIAN DAN PEMBAHASAN}

Berdasarkan hasil analisis dari setiap kategori kemampuan matematika tinggi, kemampuan matematika sedang, dan kemampuan matematika rendah. Hasil tersebut yang memenuhi dan sesuai dengan deskriptor berpikir semantik yaitu 
subjek dengan kemampuan matematika tinggi. Maka pada artikel ini yang diuraikan hanya subjek dengan kemampuan matematika tinggi sebagai berikut.

\section{Pembahasan Hasil Penelitian Subjek Kemampuan Matematika Tinggi (S-} 1)

\section{a. Memahami Masalah}

Pada bagian ini dilakukan pembahasan hasil penelitian berdasarkan pada analisis berpikir semantik (semantik thinking)siswa dalam pemecahan masalah matematis. Berpikir semantik siswa tentang identifikasi fakta, identifikasi pertanyaan yang dilakukan. Subjek S-1 menjelaskan identifikasi fakta yang dilakukan.

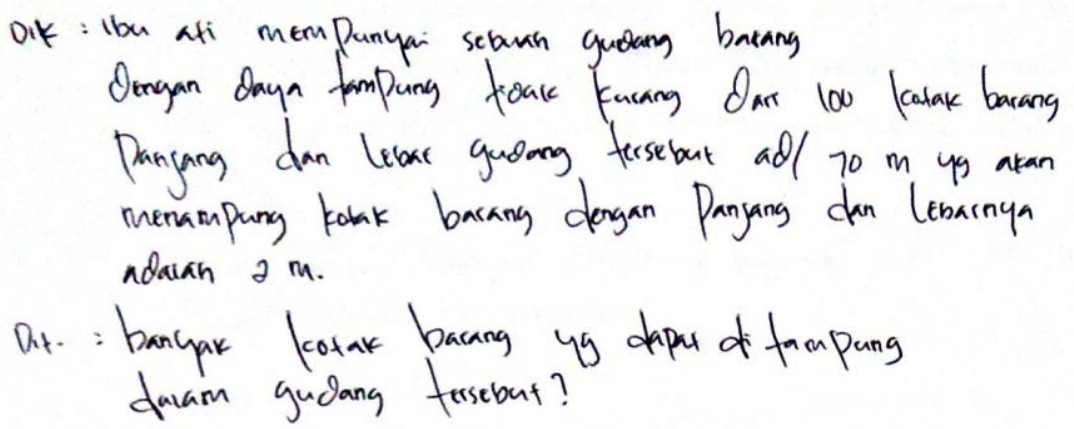

Hal ini terlihat pada saat respon subjek terhadap TPM 1 yaitu: "Ibu Ati mempunyai sebuah gudang barang dengan daya tampung tidak kurang dari 100 kotak barang, panjang dan lebar gudang tersebut adalah $70 \mathrm{~m}$ yang akan menampung kotak barang dengan panjang dan lebarnya adalah 2 m”, TPM 2 yaitu: "Sebuah mobil box pengangkut barang dengan daya angkut tidak lebih dari $500 \mathrm{~kg}$. Berat Pak Zabir adalah $60 \mathrm{~kg}$ dan akan mengangkut kotak barang yang setiap kotak beratnya $20 \mathrm{~kg}$ ". Demikian juga subjek tahu dan mengerti apa yang ditanyakan dalam TPM 1 yaitu: "Banyak kotak barang yang dapat ditampung dalam gudang tersebut?", TPM 2 yaitu: "Tahu. kotak paling banyak dapat diangkut oleh Pak Zabir dalam sekali pengangkutan?”.

Subjek menjelaskan tentang memeriksa kecukupan data yang dilakukan pada TPM, hal ini ditunjukan ketika peneliti menanyakan "Menurut kamu, untuk menyelesaikan soal ini, apakah data/informasi yang ada pada soal sudah cukup atau belum?" dan subjek menjawab "Sudah". Hasil tersebut menunjukan bahwa subjek bisa memeriksa kecukupan data/informasi yang ada sudah cukup.

Berdasarkan uraian di atas dalam memahami masalah, aspek - aspek yang dapat diungkap dan dikaitkan dengan deskriptor berpikir semantik (semantic thinking) yaitu, subjek menjelaskan identifikasi fakta yang dilakukan, subjek tahu apa yang ditanyakan dalam TPM, subjek merasa yakin bahwa data/informasi sudah cukup jelas. Menurut lee (suharna, 2013: 160) pada lave recall yaitu mendeskripsikan apa yang dialaminya, menafsirkan situasi berdasarkan ingatan 
akan pengalamannya, dan berupaya untuk meniru cara - cara yang telah diamatinya.

\section{b. Merencanakan Pemecahan}

Merencanakan pemecahan penyelesaian masalah, subjek menjelaskan tentang bagaimana memeriksa lambang/simbol yang dilakukan.

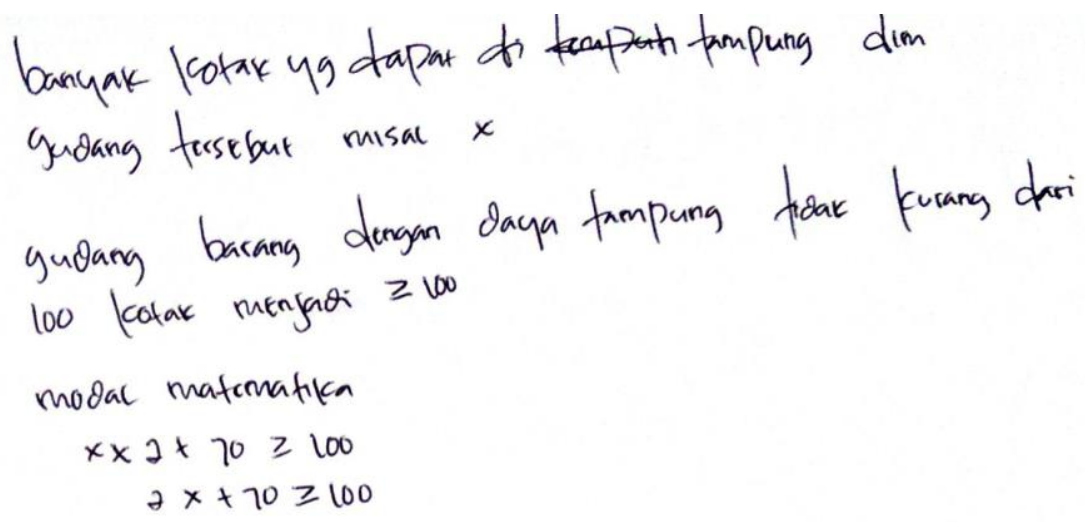

Respon subjek terhadap TPM 1 yaitu: "Banyak kotak yang dapat ditampung dalam gudang tersebut misalkan $X$ dan tidak kurang dari 100 kotak menjadi $\geq$ 100”, TPM 2 yaitu: "Bisa: "Sebuah mobil box pengangkut barang daya angkut tidak lebih dari $500 \mathrm{~kg}$ adalah $\leq 500$ dan kotak paling banyak misalkan adalah $X$ ”. Seperti yang minggu lalu (TPM 1), cuman ada beda”. Ketika peneliti menanyakan : "Kenapa menjadi $\geq 100$ ?", respon subjek: "Karena : tidak kurang dari 100 maka menjadi $\geq 100$ ". hal ini menunjukan bahwa subjek mampu menjelaskan tentang bagaimana memeriksa lambang/simbol yang ada.

Subjek menjelaskan tentang bagaimana menyusun lambang/simbol dalam merepresentasikan data. Pada tahap ini subjek bisa menyusun lambang/simbol yang ada dan merepresentasikan data, hal ini didasarkan pada respon subjek TPM 1 yaitu " $X x 2+70 \geq 500$ menjadi $2 x+70 \geq 100$ ", TPM 2 yaitu: “ $X x 20+60 \leq$ 500 menjadi $20 x+60 \leq 500$ ". Terlihat bahwa subjek mengetahui dan paham bagaimana menyusun dan merepresentasi data yang dilakukan. Demikian juga subjek menjelaskan bagaimana memilih strategi pemecahan yang dilakukan. Ketika peneliti menanyakan "Langkah - langkah yang akan kamu gunakan dalam menyelesaikan soal ini?" respon subjek "Hmmm...kumpulkan yang sejenis lalu menyelesaikan”. Subjek menjelaskan tentang memilih strategi pemecahan yaitu subjek mengumpulkan yang sejenis agar dapat mempermudah dalam perhitungan.

Berdasarkan uraian di atas jika dikaitkan dengan deskriptor berpikir semantik (semantic thinking), maka dalam menyusun rencana subjek berpikir semantik. subjek mampu menjelaskan tentang bagaimana memeriksa lambang/simbol yang ada dan Subjek bisa menjelaskan tentang memilih strategi pemecahan yaitu subjek mengumpulkan yang sejenis agar dapat mempermudah dalam perhitungan. 


\section{c. Melaksanakan Rencana}

Melaksanakan rencana pemecahan dalam menyelesaikan masalah, subjek menjelaskan bagaimana mengembangkan strategi pemecahan menggunakan operasi dengan baik. Ketika peneliti menanyakan Kira - kira operasi apa yang digunakan untuk mengerjakannya?, respon subjek yaitu: "Tambah, kurang, dan bagi". Hal ini menunjukan bahwa subjek mengerti mengembangkan strategi pemecahan masalah yang dilakukan.

Selanjutnya subjek menjelaskan tentang keterampilan menghitung. Ketika peneliti menanyakan pada TPM 1 "Bagaimana kamu menggunakan operasi itu?", respon subjek " $2 x+70 \geq 100$ samakan sejenis $2 x \geq 100$-70 trus dihitung”,

$$
\begin{aligned}
2 \mathrm{x}+70 \quad & \geq 100 \\
2 \mathrm{x} & \geq 100-70 \\
2 \mathrm{x} & \geq 30 \\
\mathrm{X} \geq \frac{30}{2} & \\
& \mathrm{X} \geq 15
\end{aligned}
$$

untuk TPM 2 yaitu "20x $+60 \leq 500$ kumpulkan sejenis $20 x \leq 500-60$ dihitung”.

$$
\begin{aligned}
20 x+60 \quad & \leq 500 \\
& 20 x \leq 500-60 \\
20 x & \leq 440 \\
X & \leq \frac{440}{20}
\end{aligned}
$$

respon subjek terbut menunjukan bahwa subjek menjelaskan tentang keterampilan menghitung yang dilakukan dengan baik. Kemudian ketika peneliti menanyakan tentang pekerjaan subjek "Ketika menyelesaikan apakah kamu menggunakan gambar?", respon subjek "Saya, ada gambar". Melihat pernyataan tersebut bahwa subjek mengkomunikasikan idenya dalam bentuk gambar sebagai berikut:
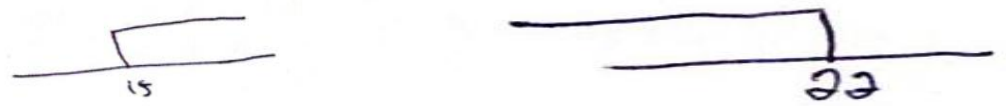

Berdasarkan uraian di atas dalam melaksanakan rencana jika dikaitkan dengan deskriptor berpikir semantik yaitu subjek menjelaskan bagaimana mengembangkan strategi pemcahan yang dilakukan, subjek menjelaskan tentang keterampilan menghitung yang dilakukan, dan subjek menjelaskan keterampilan geometri terkait dengan lambang/simbol yang mempunyai makna.

\section{d. Memeriksa Kembali}

Pada tahap memeriksa kembali adalah subjek menyadari ada kesalahan pada saat menggunakan keterampilang menghitung dan geometri. Ketika peneliti 
menanyakan pada TPM 1 "Pada saat menghitung apakah ada kesalahan yang dibuat?", respon subjek “Ada, tapi sudah dibuat ulang”, kemudian "Pada saat mengambar apakah ada kesalahan juga yang dibuat?", respon subjek "Tidak ada”, hal ini juga sama pada TPM 2. Jawaban tersebut menunjukan bahwa subjek menyadari ad kesalahan pada saat menggunakan keterampilan menghitung dan geometri terkait lambang/simbol yang mempunyai makna.

Berikutnya subjek menjelaskan apakah jawaban yang diperoleh itu mempunyai makna, subjek yakin bahwa jawaban yang diperoleh sudah mempunyai makna. Hal ini dikuatkan dengan respon subjek yaitu "Sudah. Karena $x \geq 15$,

$$
\begin{gathered}
2 x+70 \geq 100 \\
2(15)+70 \geq 100 \\
30+70 \geq 100 \\
100 \geq 100
\end{gathered}
$$

jadi banyak kotak yang dapat ditampung dalam gudang tersebut paling banyak 15 kotak. Dengan demikian subjek jawaban yang diperoleh itu mempunyai makna, hal ini juga sama dengan hasil kerja siswa:

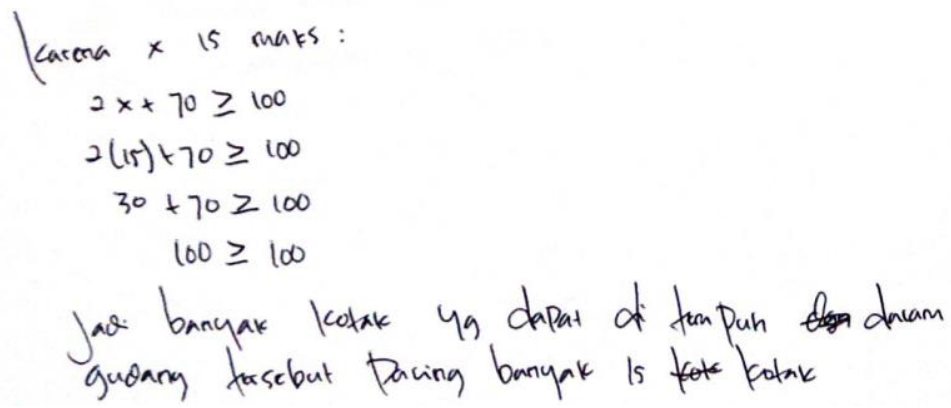

Berdasarkan uraian di atas dalam memeriksa kembali yaitu subjek Menyadari ada kesalahan pada saat menggunakan keterampilan menghitung dan geometri terkait lambang/simbol yang mempunyai makna dan subjek menjelaskan apakah jawaban yang diperoleh itu mempunyai makna dari lambang/simbol matematika.

Berdasarkan apa yang telah diuraikan maka berpikir semantik (semantic thinking) siswasmp berkemampuan matematika tinggi terlihat pada tabel berikut:

\begin{tabular}{|c|l|cr|}
\hline $\begin{array}{c}\text { Langkah } \\
\text { Pemecahan }\end{array}$ & \multicolumn{4}{|c|}{ Hasil Analisis Data } \\
\hline $\begin{array}{c}\text { Memahami } \\
\text { masalah }\end{array}$ & $\begin{array}{l}\text { 1) subjek bisa menjelaskan identifikasi fakta, 2) menjelaskan } \\
\text { identifikasi pertanyaan yang telah dilakukan, 3) subjek } \\
\text { menjelaskan tentang kecukupan data yang dilakukan. }\end{array}$ \\
\hline $\begin{array}{c}\text { Merencanakan } \\
\text { rencana }\end{array}$ & $\begin{array}{l}\text { lambang/simbol yang digunakan, 2) subjek mampu menjelaskan } \\
\text { tentang } \\
\text { merepresentasikan data dengan tepat, }\end{array}$ \\
\end{tabular}




\begin{tabular}{|c|c|}
\hline & $\begin{array}{l}\text { tentang memilih strategi pemecahan yaitu menyamakan yang } \\
\text { sejenis atau sama untuk mempermudah pada saat menghitung. }\end{array}$ \\
\hline $\begin{array}{l}\text { Melaksanakan } \\
\text { rencana }\end{array}$ & 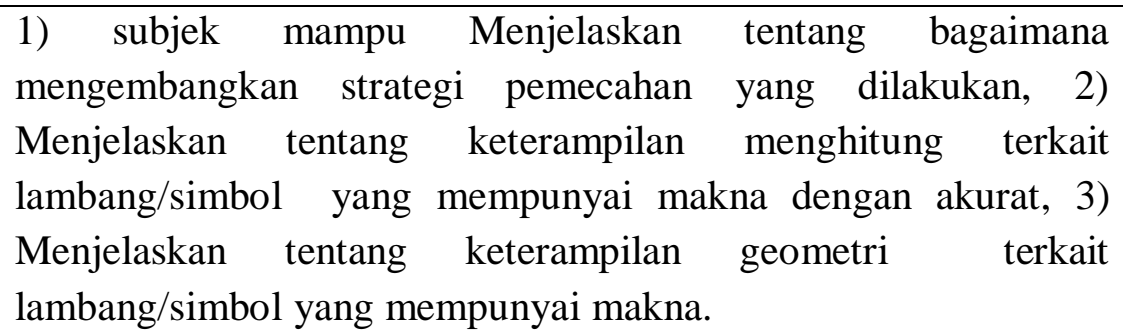 \\
\hline $\begin{array}{c}\text { Memeriksa } \\
\text { kembali }\end{array}$ & $\begin{array}{l}\text { 1) subjek menyadari tidak ada kesalahan pada saat menggunakan } \\
\text { keterampilan menghitung dan geometri terkait lambang/simbol } \\
\text { yang digunakan, 2) subjek mampu menjelaskan tentang jawaban } \\
\text { yang diperoleh mempunyai makna dari lambang/simbol yang ada }\end{array}$ \\
\hline
\end{tabular}

\section{KESIMPULAN}

\section{Berpikir Semantik (Semantic Thinking) Siswa Dalam Menyelesaikan Pemecahan Masalah Matematis.}

a. Berpikir semantik berdasarkan subjek kemampuan matematika tinggi Berpikir semantik siswa dalam menyelesaikan pemecahan masalah matematis dimulai dari informasi/pengetahuan yang digunakan untuk merespon berasal dari dalam diri terhadap fenomena - fenomena yang memerlukan jawaban fakta dan mencari jawaban sendiri dari persoalan yang dingkat, menyadari kesalahan dan memperbaikinya, dan mengkomunikasikan ide dengan simbol atau gambar.

b. Berpikir semantik berdasarkan subjek kemampuan matematika sedang Berpikir semantik siswa dalam menyelesaikan pemecahan masalah matematis dimulai dariinformasi/pengetahuan yang digunakan untuk merespon berasal dari dalam diri (internal), menjelaskan yang telah dilakukan terkait lambang atau simbol, dan mengkomunikasikan ide dengan simbol atau gambar yang selaras.

c. Berpikir semantik berdasarkan subjek kemampuan matematika rendah Berpikir semantik siswa dalam menyelesaikan pemecahan masalah matematis dimulai dariinformasi/pengetahuan yang digunakan untuk merespon berasal dari dalam diri (internal), kemudian menyusun lambang atau simbol dan merepsentasikan data. 


\section{DAFTAR PUSTAKA}

Abdussakir. 2014. Proses Berpikir Mahasiswa Dalam Menyusun Bukti Matematis Dengan Strategi Semantik. Jurnal Pendidikan Sains. Vol.2, No.3, Hal 132-140. Issn: 2338-9117.

Achmad, munif. 2012. Pengantar ilmu pendidikan. Semarang: UPT UNNES PRESS.

Angkotasan, N. 2014. Keefektifan model problem based learning ditinjau dari kemampuan pemecahan masalah matematis. Delta-Pi: Jurnal matematika dan pendidikan matematika. Vol. 3, No 1. ISSN. 2089-855X.

Depdiknas. 2003. Undang-Undang RI Nomor 23, Tahun 2003, tentang Sistem Pendidikan Nasional.

Jazeri, M. 2012. Semantik "teori memahami makna bahasa". STAIN Tulungagung Press.

Ratumanan, dan laurens. 2006. Evaluasi Hasil Belajar Siswa yang Eleven dengan Kurikulum Berbasis Kompetensi. Surabaya. Pengkajian Pengembangan Pendidikan Indonesia Timur.

Siswono, dkk. 2007. Proses berfikir kreatif siswa dalam memecahkan dan mengajukan masalah. Jurnal ilmu pendidikan. Vol 15, no 1.

Sugiyono. (2016). Metode Penelitian Kuantitatif, Kualitatif, Dan Kombinasi (Mixed Methods). Bandung: Alfabeta

Suharna, H \& Dkk. 2013.Berpikir Reflektif Mahasiswa Dalam Menyelesaikan Masalah Matematika. Universitas Khairun, Universitas Negeri Malang, Universitas Negeri Malang, Universitas Negeri Malang. Knpm V, Himpunan Matematika Indonesia.

Suharna, H. 2013. Berpikir Reflektif (Reflective Thinking) Siswa Sd Berkemampuan Matematika Tinggi Dalam Pemahaman Masalah Pecahan. Universitas Khairun Ternate. Prosiding. ISBN : 978-979-163538-7.

Suherman, F. Windari, dan F. Dwina. 2014. Meningkatkan Kemampuan Pelajaran 2013/2014 Dengan Menggunakan Strategi Pembelajaran Inkuiri. Jurnal Pendidikan Matematika, vol (3). Hal 19-253.Pemecahan Masalah Matematika Siswa Kelas VIII SMPN 8 Padang Tahun

Wardhani, S., dkk. 2010. Pembelajaran kemampuan pemecahan masalah matematika di SMP. Yogyakarta: PPPPTK. 